\title{
Estimating Market Power of Tea Processing Sector
}

\author{
Jeevika Weerahewa*
}

\begin{abstract}
It is generally believed that the food processing sector can exercise market power on raw material producers and final consumers. The objective of this study was to assess the degree of oligopoly and oligopsony power of the tea-processing sector. A partial equilibrium model was developed for the world market for tea, treating India, Kenya and Sri Lanka as raw tea producers and Canada, United Kingdom and the United States of America as tea consumers. An imperfectly competitive tea-processing sector was incorporated in the model allowing conjectural variation elasticity to represent the degree of market power. The model was econometrically estimated using the two-stage least square estimation procedure. Results of the econometric estimation show that all the market power estimates are statistically significant. The conjectural elasticity values in the input market are 0.0516, 0.0015 and 0.1657 for India, Kenya and Sri Lanka respectively. The conjectural variation elasticity in the output market is 0.1273. The elasticity of supply with respect to own prices are 0.0791, 0.2268 and 0.2060 for India, Kenya and Sri Lanka respectively. The elasticity of demand with respect to own prices are -0.4720, -0.1556 and -0.1237 for Canada, United Kingdom and the United States respectively. The resulting Learner Index for Sri Lanka is very small indicating that Sri Lankan tea producers are not significantly exploited by tea processors.
\end{abstract}

\section{Introduction}

Market power exists when one group of marketing agents has a higher bargaining power than the other group of marketing agents. When sellers exert market power over buyers it is called oligopoly power and when buyers exert market power over sellers, it is called oligopsony power. Economists and policy makers are interested in the degree of market power in different industries as its presence implies a market failure. When markets fail to function, resource allocation carried out by the market mechanism is inefficient and government intervention is necessary to allocate resources efficiently.

* The author is Senior Lecturer, Department of Agricultural Economics and Business Management, Faculty of Agriculture, University of Peradeniya. 
A number of marketing agents in an industry is one of the indicators of market power. If there are large number of buyers and sellers, the market is considered to be perfectly competitive. It is generally considered that many foodprocessing sectors exert market power on the raw material sellers and final consumers, since the number of food processing firms is much smaller than the number of raw material producing firms and the number of consumers. Concentration ratio, which shows the market share of the top- most firms, is another commonly used indicator for measuring market power. If the top four firms account for more than 80 percent of the market, that market is considered to be imperfect.

When market power is assessed using the above measures, firm behaviour is not explicitly modeled and no statistical tests are performed. Many believe that the types of strategic interactions among the firms, rather than the number of firms determine the degree of market power, and econometric techniques can be used to estimate the degree of market power (Appelbaum, 1979, 1982; Azzam and Pagoulatos, 1990; Roberts, 1984; Rude, 1992). They use conjectural variation elasticity, which shows the percentage change in purchases and/or sales of the industry due to one percent change in the purchases and/or sales of the firm as an indicator of market power. These techniques are superior to measures used earlier as they can statistically test the types of strategic reactions present in a market. The objective of this study is to econometrically estimate the degree of oligopoly and oligopsony power in the tea-processing sector.

The paper is organised as follows. The next section provides a background to the tea industry. The following section presents an econometric model that can be used to assess the degree of market power. An empirical model is presented next. Results of the estimation are presented in the subsequent sections followed by the conclusion.

\section{Background}

The tea sector is a vital component of the Sri Lankan economy providing 1.23 percent to the Gross Domestic Product (GDP), 14 percent to the foreign exchange earnings, and 6 percent of employment (Central Bank of Sri Lanka, 2002). Sri Lanka is the leading tea exporter in the world market and mainly produces and exports bulk tea. Sri Lanka's share in the export market is 20 percent. Kenya and India, the second and third leading tea exporters had market shares of 13 and 19 percent respectively in 2002 (International Tea Committee, 2003). Table 1 shows the present status of tea production and exports in the world. 
Table 1: Present Status of Tea Production and Exports in the World, 2002.

\begin{tabular}{|c|c|c|c|c|}
\hline \multirow[t]{2}{*}{ Country } & \multicolumn{2}{|c|}{ Production } & \multicolumn{2}{|c|}{ Exports } \\
\hline & $\mathrm{Mt}$ & Percentage & $\mathrm{Mt}$ & Percentage \\
\hline India & $826,165 *$ & 27.27 & $190,000^{*}$ & 13.39 \\
\hline Bangladesh & $52,863^{*}$ & 1.74 & 13,653 & 0.96 \\
\hline Sri Lanka & 310,032 & 10.23 & 285,985 & 20.15 \\
\hline Indonesia & 166,027 & 5.48 & 100,185 & 7.06 \\
\hline China & $715,000 *$ & 23.60 & 252,273 & 17.77 \\
\hline Iran & $48,000 *$ & 1.58 & $3,000 *$ & 0.21 \\
\hline Japan & $9,000 *$ & 0.29 & 806 & 0.06 \\
\hline Turkey & $142,000 *$ & 4.68 & 5,160 & 0.36 \\
\hline Vietnam & $84,000 *$ & 2.77 & 74,812 & 5.27 \\
\hline Kenya & 287,044 & 9.47 & 267,721 & 18.86 \\
\hline Malavi & 39,185 & 1.29 & 39,385 & 2.77 \\
\hline Uganda & 33,831 & 1.11 & 31,073 & 2.19 \\
\hline Argentina & $62,000^{*}$ & 2.04 & $54,000^{*}$ & 3.80 \\
\hline World Total & $3,028,754 *$ & 100 & $1,419,397^{*}$ & 100 \\
\hline
\end{tabular}

Source: International Tea Committee, 2003

Table 2: Present Status of Tea Imports in the World.

\begin{tabular}{lcr}
\hline Country & Mt & Percentage \\
\hline Russian Federation & 162,601 & 12.18 \\
Other CIS & $49,000^{*}$ & 3.67 \\
United Kingdom & 136,598 & 10.23 \\
Pakistan & 97,827 & 7.33 \\
USA & 93,474 & 7.00 \\
Egypt & 78,942 & 5.91 \\
Japan & 51,487 & 3.86 \\
Iran & $40,600^{*}$ & 3.04 \\
Iraq & $75,000^{*}$ & 5.62 \\
Morocco & $43,000^{*}$ & 3.22 \\
Poland & 31,000 & 2.32 \\
World Total & $1,334,900$ & 100 \\
\hline So: In
\end{tabular}

Source: International Tea Committee, 2003

Blending of black tea to produce value-added tea is done by the tea processing firms. Evidence suggest that Multi-National Corporations such as Brook Bond, Lipton, Twining and Lyonnes Tetley control 80 percent of the world tea trade
(Chamlin, 1992; Athukorala and Huynh, 1987). This concentration in the industry offers an opportunity for blenders to exert market power.

The United Kingdom had been the leading tea importer in the world 
for a long period of time. At present Middle Eastern countries, Pakistan and United States of America are the leading tea importers. Table 2 shows the present status of tea imports in the world.

\section{Econometric Model to Estimate Market Power}

When firms have oligopoly power, they can influence the output price to some degree and when they have oligopsony power, they can influence the input price to some degree. The degree of oligopoly and oligopsony power depends on the strategic interactions with other firms. The equilibrium with and without oligopoly power is shown in figure 1 and the equilibrium with and without oligopsony power is shown in figure 2. Oligopoly power is

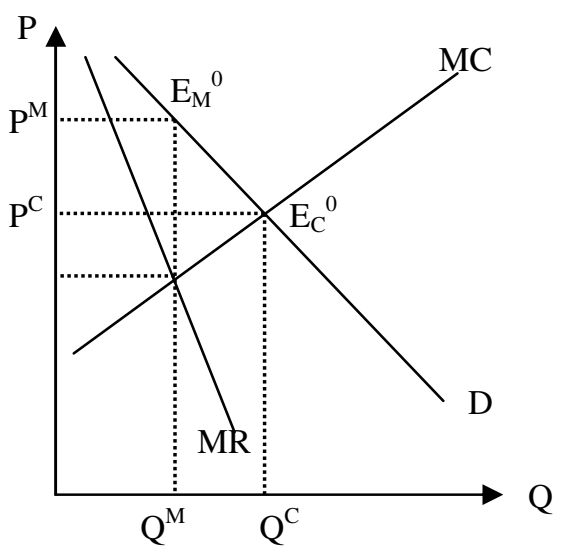

Figure 1: Equilibrium in an output market normally exercised by suppliers of an output and oligopsony power is normally exercised by demanders of a raw material. Therefore, figure 1 and figure 2 show the equilibrium of an output market and the equilibrium of an input market respectively. In figure 1 demand for the output is shown by $\mathrm{D}$ and the marginal cost of the suppliers is shown by MC. Prices and quantities are determined in a competitive market when D intersects with $\mathrm{MC}$ and those in a monopoly market are determined when MR intersects with MC. In figure 2 demand for the raw material is shown by DD and the supply of the raw material is shown by $\mathrm{S}$. Prices and quantities in a competitive market are determined when DD intersects $S$ and those in a monopsony market are determined when MIC intersects with DD.

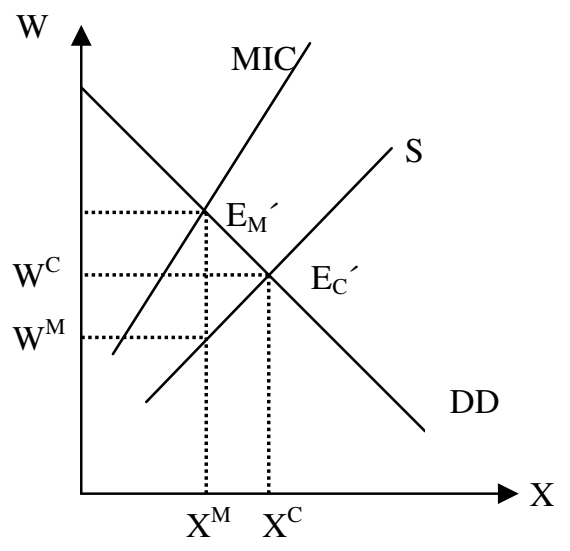

Figure 2: Equilibrium in an input market 
When there is no oligopoly power and oligopsony power, i.e., in a perfect competition context, equilibria of the markets are shown by $\mathrm{E}_{\mathrm{C}}{ }^{\circ}$ and $\mathrm{E}_{\mathrm{C}}{ }^{\prime}$ respectively. In the monopoly market and monopsony market, equilibria are shown by $\mathrm{E}_{\mathrm{M}}{ }^{\circ}$ and $E_{M}{ }^{\prime}$ respectively. An oligopoly market can lie anywhere between $\mathrm{E}_{\mathrm{C}}{ }^{\circ}$ and $\mathrm{E}_{\mathrm{M}}{ }^{\circ}$ and an oligopsony market can lie anywhere between $\mathrm{E}_{\mathrm{C}}{ }^{\prime}$ and $\mathrm{E}_{\mathrm{M}}{ }^{\prime}$, depending upon the degree of market power, which depends on the conjectural variation elasticity and elasticity of demand / elasticity of supply in oligopoly/oligopsony markets respectively.

The conjectural approach to measuring market power assumes that firms simultaneously and independently choose output and input levels, given their beliefs about their rivals' reactions to their choice. These assumptions are called conjectural variations. Azzam and Pagoulatos (1990) modeled the problems of firms using the conjectural approach and specified the profit equation of a firm in an industry with $n$ firms who exert both oligopoly and oligopsony power as follows.

$\operatorname{Max} \pi^{j}=T R^{j}-T V C^{j}$

Where

$$
\begin{aligned}
& T R^{j}=P \cdot q^{j} \\
& T V C^{j}=W_{x} x^{j}+W_{y} y^{j} \\
& q^{j}=f\left(x^{j}, y^{j}, z^{j}\right)
\end{aligned}
$$

$$
\begin{aligned}
P & =P(Q) \\
Q & =\sum_{j=1}^{j=n} q^{j} \\
W_{x} & =W_{x}(X) \\
X & =\sum_{j=1}^{j=n} x^{j}
\end{aligned}
$$

where, $\pi^{j}$ is profit, $T R^{j}$ is the total revenue, $T V C^{j}$ is the total variable cost, $q^{j}$ is the output and $x^{j}$ and $y^{j}$ are the input levels of $X$ and $Y$ respectively of the $j^{\text {th }}$ firm. $P$ is output price, $W_{x}$ is price of $X$ and $W_{y}$ $i$ price of $Y$.

The first order condition with respect to $x^{j}$ is,

$\left[P+Q \cdot \theta^{j} \cdot \frac{\partial P}{\partial Q}\right] \cdot M P_{x}=\left[W_{x}+X \cdot \phi^{j} \frac{\partial W_{x}}{\partial X}\right]$

where

$\phi^{j}=\left(\partial X / \partial x^{j}\right) x^{j} / X \quad$ is the conjectural elasticity in the input market and $\theta^{j}=\left(\partial Q / \partial q^{j}\right) q^{j} / Q$ is the conjectural elasticity in the output market for the $j^{\text {th }}$ firm. $\theta^{j}$ shows the $j^{\text {th }}$ firm's perception of the present change in the production by all firms in the industry in reaction to a one percent change in the $j^{\text {th }}$ firm's production. $\Phi^{j}$ shows the $j^{\text {th }}$ firm's perception of the percent change in the purchases by all firms in the industry in reaction to a one percent change in the $j^{\text {th }}$ firm's purchases. 
The first term in the expression (2) is the first derivative of total revenue with respect to quantity of output and it is termed as conjectural marginal revenue $(C M R)$ following Quirmbach (1988). The term on the right side of the above expression is the first derivative of total cost with respect to quantity of corresponding input and is termed as conjectural marginal input cost $(C M I C)$ following Chen and Lent (1992). It is clear that when $\Phi^{j}$ and $\theta^{j}$ are equal to zero, this condition reduces to the competitive outcome and when $\Phi^{j}$ and $\theta^{j}$ are equal to one, this condition reduces to the monopoly and monopsony outcome.

The first order condition with respect to $y_{j}$ (assuming that the processing firms can not influence $W_{y}$ is,

$$
\left[P+Q \cdot \theta^{j} \cdot \frac{\partial P}{\partial Q}\right] \cdot M P_{y}=W_{y}
$$

In elasticity terms the conditions in (2) and (3) can be written as (4) and (5) respectively.

$$
\begin{aligned}
& P \cdot\left(1+\frac{\theta^{j}}{\eta}\right) \cdot M P_{x}=W_{x} \cdot\left(1+\frac{\phi^{j}}{\varepsilon}\right) \\
& P \cdot\left(1+\frac{\theta^{j}}{\eta}\right) \cdot M P_{y}=W_{y}
\end{aligned}
$$

where $\eta=(\partial Q / \partial P) P / Q$ is the output demand elasticity and $\varepsilon=\left(\partial X / \partial W_{x}\right) W_{x} / X$ is the farm product supply elasticity. $\theta^{j} / \eta$ represents the Lerner index for oligopoly power, which represents the degree to which a firm can set output price above marginal cost. The higher the conjectural elasticity in the output market, the higher the oligopoly power. The lower the demand elasticity (more inelastic the demand), the higher the oligopoly power. $\phi^{j} / \varepsilon$ represents the Lerner index for oligopsony power, which represents the degree that firms can set input price below the value of the marginal product. The higher the conjectural elasticity in the input market, the higher the oligopsony power. The lower the supply elasticity (more inelastic the supply) the higher the oligopsony power.

Azzam and Pagoulatos (1990) specify the behavioral functions as the first order conditions shown in the above two equations. In contrast, Gollop and Roberts (1979) restrict the conjectural elasiticity in the input market to be zero and specify the behavioral functions as the first order conditions shown in similar equations as above.

Schroeter (1988) assumed a
fixed proportions technology between output and raw material and expressed both input and output by the same variable. He defined a cost function for the other inputs except for raw input, and defined the problem of a firm facing an oligopsonistic input market and 
oligopolistic output market as follows.

$$
\pi^{j}=P \cdot q^{j}-W_{x} \cdot q^{j}-C\left(q^{j}\right)
$$$$
P=P(Q)
$$$$
Q=\sum_{j=1}^{j=n} q^{j}
$$$$
W_{x}=W_{x}(Q)
$$

This allows him to obtain the first order condition with respect to $q^{j}$, which is,

$$
P \cdot\left(1+\frac{\theta^{j}}{\eta}\right)=W \cdot\left(1+\frac{\theta^{j}}{\varepsilon}\right)+M C^{j}
$$

Schroeter (1988) specifies the above condition as the supply function of an oligopsonistic and oligopolistic firm, and hence as a behavioral function. This approach could be considered a dual approach since it does not show the production function parameters explicitly. Wann and Sexton (1992) and Huang and Sexton (1996) followed Schroeter and specified the supply side accordingly.

Appelbaum (1982) defines the problem of a firm facing competitive input prices and oligopolistic output market as follows.

$$
\begin{aligned}
& \pi^{j}=P \cdot q^{j}-C\left(q^{j}\right) \\
& P=P(Q) \\
& Q=\sum_{j=1}^{j=n} q^{j}
\end{aligned}
$$

The first order condition with respect to $q^{j}$ is,

$$
M C^{j}=P \cdot\left(1+\frac{\theta^{j}}{\eta}\right)
$$

This condition provides the supply of an oligopolistic firm and hence is a behavioral function. It is clear that when $\theta^{j}$ is equal to zero, this condition reduces to the competitive outcome. When $\theta^{j}$ is equal to one, this condition reduces to the monopoly and monopsony outcome. Lopez (1984), Quirmbach (1988), Buschena and Perloff (1991), Rude (1992), Cranfield (1995), Bhuyan and Lopez (1995), and Duff (1996) followed Appelbaum (1982) and specified the supply side accordingly.

According to Roberts (1984) there exists a shadow price variable profit function which is dual to oligopolists production function. The form of the function according to the first order conditions (2) and (3) is as follows.

$$
\pi^{j}=\pi\left(C M R, C M I C, W_{y}, z\right)
$$


Now Hotelling's Lemma can be used obtain the input demand and output supply functions.

$x^{j}=-\frac{\partial \pi\left(C M R C M I C, W_{y}, Z\right)}{\partial C M I C}$

$y^{j}=-\frac{\partial \pi\left(C M R, C M I C, W_{y}, Z\right)}{\partial W_{y}}$

$q^{j}=-\frac{\partial \pi\left(C M R, C M I C, W_{y}, Z\right)}{\partial C M R}$

\section{Empirical Model and Data}

The above model is extended to the world tea market. Three major producers-India, Kenya and Sri Lanka-were considered and three major consumers Canada, U.K. and U.S.A were considered. The rest of the producing countries were pooled and referred to as the "rest" and the rest of the consuming countries were pooled and referred to as the "others". A single processing sector was considered. Conjectural variation elasticity values in input market $(\phi)$ were assumed to be constants over time and they were considered to be different among different producers. Conjectural variation elasticity in the output market was considered to be a constant over the years and across countries (Weerahewa, 1996).
Production, values and quantities of exports were obtained from the International Tea Committee. The prices and the quantities of final tea demanded by the U.S.A., U.K. and Canada were obtained from the World Tea Situation, Annual Abstract of Statistics published by the Central Statistical Office and Food Industries published by Statistics Canada. Expenditure on research investment in Sri Lanka was obtained from the International Service for National Agricultural Research reports and from the Annual Report of the Sri Lanka Tea Board. Promotion expenditure was also obtained from the Annual Report of the Sri Lanka Tea Board. Canadian advertising expenditure data was obtained from various years of the Annual Summary of Advertising Expenditure in Canada (Media Measurement Services, Inc.). For the U.S.A., similar data were taken from various years of $\mathrm{Ad} \$$ Expenditure (Leading National Advertisers). Population, consumer and producer price indices, exchange rates and GDP values were obtained from the IMF's International Financial Statistics Yearbook.

Supply and demand equations were first estimated as single equations. Next, supply and demand equations were estimated with the price linkage equations simultaneously. The profit system was estimated using the LSQ technique in TSP (TSP International 1997). 


\section{Results of the Estimation Tea Supply}

The Sri Lankan supply function was estimated with a lagged dependent variable, current price variable, research expenditure and a time trend. The function was estimated in the linear form. The research expenditure variable was taken as the reciprocal of research expenditure lagged by 19 years. The elasticity of supply with respect to price at the mean of the sample is 0.206. Results indicate that the research effect is positive in every observation, producing an elasticity of 0.1551 at the mean of the sample. The Indian and Kenyan supply equations were estimated in log-log form with a lagged dependent variable, current price and the time trend. The price elasticities were estimated to be 0.120 and 0.226 respectively. There are increasing trends in tea production in India and Kenya. The supply equation for the rest of the world was estimated in linear form with a lagged dependent variable, and the current price. The price elasticity was estimated to be 0.014 at the mean (table 3 ).

\section{Tea Demand}

The final demand functions for the U.S., U.K. and Canada were estimated with log-log functional forms. Own price elasticities were $0.1237, \quad 0.1556$ and 0.4720 (in absolute values) for the U.S, U.K. and Canada respectively. In the U.S function, coffee price and tea price share the same coefficient and produced a cross price elasticity of 0.1237 . The cross price elasticities in the U.K. and Canada were 0.0383 and 0.1826 respectively (table 3 ).

Table 3: Supply and Demand Elasticities.

\begin{tabular}{lllrr}
\hline \multicolumn{1}{c}{ Block } & Country & Variable & \multicolumn{1}{c}{ Elasticity } & \multicolumn{1}{c}{ s statistics } \\
\hline Raw Tea & Sri Lanka & Own price & 0.2060 & $(3.69)$ \\
Supply & & Research & 0.1552 & $(4.91)$ \\
& India & Current price & 0.0791 & $(3.63)$ \\
& Kenya & Current price & 0.2268 & $(2.81)$ \\
& Row & Current price & 0.0143 & $(0.53)$ \\
Final & & & & \\
Tea & U.S.A. & Own price & -0.1237 & $(4.73)$ \\
Demand & & Coffee price & 0.1237 & $(4.73)$ \\
& & Advertising & 0.1171 & $(2.38)$ \\
& U.K. & Own price & -0.1556 & $(6.31)$ \\
& & Coffee price & 0.0383 & $(2.62)$ \\
& & Advertising & 0.0085 & $(5.26)$ \\
& Canada & Own price & -0.4720 & $(5.86)$ \\
& & Coffee price & 0.1826 & $(6.03)$ \\
& & Advertising & 0.1936 & $(2.90)$ \\
\hline
\end{tabular}




\section{Profit Block}

The elasticities generated from the shadow price profit system are presented in table 4. All the own price coefficients in the derived demand functions have expected negative signs and the own price coefficients in the supply functions have expected positive signs. All the elasticity estimates are statistically significant ${ }^{1}$.

Cross price elasticities of demand for Sri Lankan tea with respect to shadow prices in India and Kenya are positive, suggesting that they could be substitutes for Sri Lankan tea. The Rest of the World (ROW) tea could be a complement to Sri Lankan tea. The elasticity of
Sri Lankan tea with respect to output price is negative suggesting that Sri Lankan tea is an inferior input in the production of final tea. This suggests that any investment made to increase the output demand may decrease the demand for Sri Lankan tea.

The level of promotion expenditure by Sri Lanka lagged by one year made is included as an exogenous variable in the input demand functions. The own promotion elasticity for Sri Lanka is 0.0026. The cross promotion elasticities for India and Kenya are positive and small indicating that they can be considered as substitutes for Sri Lankan tea. The cross promotion elasticity with respect to ROW tea is negative.

Table 4: Elasticities Generated from the Profit Block under Imperfect Condition.*

\begin{tabular}{lllllll}
\hline Prices & Sri Lanka & India & Kenya & ROW & Output & $\begin{array}{l}\text { Conjectural } \\
\text { Elasticity }\end{array}$ \\
\hline $\begin{array}{l}\text { Sri } \\
\text { Lanka }\end{array}$ & -0.2824 & 0.1573 & 0.0897 & -0.1334 & -0.0022 & 0.1657 \\
India & 0.0834 & -0.4631 & 0.2479 & 0.0519 & 0.0031 & 0.0516 \\
Kenya & 0.0268 & 0.1399 & -0.1927 & 0.0237 & -0.0013 & 0.0015 \\
ROW & -0.0347 & 0.0254 & 0.0206 & -0.0176 & -0.0001 & 0.0091 \\
Output & 0.0015 & -0.0044 & 0.0029 & 0.0003 & 0.0001 & 0.1273 \\
\hline
\end{tabular}

* All the elasticities are statistically significant at 0.01

\footnotetext{
${ }^{1}$ Standard errors of the estimates are very small and hence the resulting t-statistics are very high. According to TSP International, it is possible to obtain very large t-statistics when a small number of observations are used to estimate a large number of parameters.
} 
Table 5: Elasticities Generated from the Profit Block under Perfect Competition.*

\begin{tabular}{lrrrrr}
\hline Prices & \multicolumn{1}{c}{ Sri Lanka } & \multicolumn{1}{l}{ India } & \multicolumn{1}{c}{ Kenya } & \multicolumn{1}{c}{ ROW } & \multicolumn{1}{c}{ Output } \\
\hline Sri Lanka & -0.19 & 0.14 & 0.16 & -0.10 & 0.03 \\
India & 0.06 & -0.28 & 0.18 & 0.07 & 0.03 \\
Kenya & 0.05 & 0.13 & -0.28 & 0.04 & -0.09 \\
ROW & -0.03 & 0.04 & 0.04 & -0.02 & 0.01 \\
Output & -0.001 & -0.003 & 0.014 & -0.001 & 0.01 \\
\hline
\end{tabular}

*All the elasticities are statistically significant at 0.01

The profit system is re-estimated imposing perfect competition and treating conjectural elasticity to be equal to zero. Table 5 presents the profit system estimates of the competition model. The elasticities of input demand with respect to own prices are negative and the elasticity of output supply with respect to own price is positive, as expected. The response to promotion is similar. However, results are more elastic to those under imperfect competition. The elasticity of Sri Lankan tea demand with respect to output price is positive, (however, it is not statistically significant from zero), suggesting that Sri Lankan tea is a normal input for the production of final tea. This estimate is different from that of an imperfectly competitive model.

The $\log$ of likelihood function values of the estimation are $-2,994.52$ for the restrictive competitive model and $-2,969.96$ for the unrestrictive imperfectly competitive model. The likelihood ratio test, with a test statistic $L R=-2\left(L_{U R}-L_{R}\right)$ following ChiSquare distribution with degrees of freedom equals to the number of restrictions is used to make comparisons. The test statistic is 49.12 and the table value is 16.7 , rejecting the null hypothesis that the models are identical.

\section{Market Power}

The conjectural elasticities estimated for the ROW input markets are, 0.1657, 0.0516, 0.0015 and 0.0091 for Sri Lanka, India, Kenya and ROW respectively. The estimates of all the conjectural elasticities are statistically significant. The conjectural elasticity in the output market is 0.1273 . Lerner indices of oligopsony and oligopoly power are calculated at the regional level using the elasticities of demand and supply with respect to price. Market power in Sri Lanka, India, Kenya, ROW and the output market are $0.1083,0.0305,0.0483$ 
Table 6: Learner Indices

\begin{tabular}{llrrr}
\hline Type & Country & $\begin{array}{l}\text { Conjectural } \\
\text { elasticity }\end{array}$ & $\begin{array}{l}\text { Supply or } \\
\text { Demand } \\
\text { Elasticity }\end{array}$ & $\begin{array}{l}\text { Learner } \\
\text { index }\end{array}$ \\
\hline Oligopsony Power & Sri Lanka & 0.1657 & 0.2060 & 0.8043 \\
& India & 0.0516 & 0.0791 & 0.6523 \\
& Kenya & 0.0015 & 0.2268 & 0.0066 \\
& ROW & 0.0091 & 0.0143 & 0.6363 \\
Oligopoly Power & U.S. & 0.1273 & -0.1237 & 1.0291 \\
& U.K. & 0.1273 & -0.1556 & 0.8181 \\
& Canada & 0.1273 & -0.4720 & 0.2697 \\
\hline
\end{tabular}

and 0.4649 respectively (table 6). They are constants across the sample period, since ROW tea supply functions and output demand functions are estimated with double $\log$ forms, except for Sri Lankan and ROW tea markets. Market power in the Sri Lankan and ROW tea markets are calculated for the year 1985, at the mid of the sample. These results are consistent with some of the previous studies on market power, which found that there is a small but significant degree of market power (Azzam and Pagoulatos, 1990; Bhuyan and Lopez, 1995; Schroeter, 1988).

\section{Conclusions}

This study used an econometric technique to estimate the degree of market power in the tea processing sector. Results show that the teaprocessing industry exerts a statistically significant but relatively small oligopsony power on raw tea producers and oligopoly power on final tea consumers. Results also show that the competitive model, which is restrictive, produces different estimates for the profit system. While this indicates the importance in developing less restrictive models to perform policy analysis, the study reveals that tea producers do not exploit tea consumers in any major way.

\section{References}

Appelbaum, E. (1979). Testing Price Taking Behavior. Journal of Econometrics. 17: 283-284.

. (1982). The Estimation of the Degree of Oligopoly Power. Journal of Econometrics. 19: 287-299.

Athukorala, $\mathrm{P}$ and F.C. Huynh. (1987). Export Instability and Growth: Problems and Prospects for the Developing Economics. Kent: Croom Helm Ltd.

Azzam A. and E. Pagoulatos. (1990). Oligopolistic and Oligopsonoistic Behavior: An 
Application to the U.S. Meat Packing Industry. Journal of Agricultural Economics. 41:384-401.

Bhuyan, S. and R. Lopez. (1995). Testing for Market Power in the Food and Tobacco Manufacturing Industries. Paper Presented at AAEA meetings. Indianapolis, IN. August, 1995.

Buschena, D. and J. M. Perloff. (1991). The Creation of Dominant Market Power in the Coconut Oil Export Market. American Journal of Agricultural Economics. 73:1000-1008.

Central Bank of Sri Lanka. (2002). Annual Report. Colombo: Central Bank of Sri Lanka.

Chamlin, R. (1992). International Commodity Markets Handbook. New York: Woodhead Faulkner Ltd.

Chen, Z. and R. Lent. (1992). Supply Analysis in an Oligopsony Model. American Journal of Agricultural Economics. 74:973-979.

Cranfield, J. (1995). Adverting and Oligipoly Power in the North American Beef Industry. Thesis. M.Sc. University of Guelph.
Duff, S. (1996). The Impact of Trade Liberalization on Canadian Dairy Producers. Thesis. M.Sc. University of Guelph. Unpublished.

Gollop, F. and M. Roberts. (1979). Firm Interdependence in Oligopolistic Markets. Journal of Econometrics. 10:313-331.

Huang, S. Y. and R. J. Sexton. (1996). Measuring Returns to Innovation in an Imperfectly Competitive Market: Application to Mechanical Harvesting of Processing Tomatoes in Taiwan. American Journal of Agricultural Economics. 489500.

International Tea Committee. (2003). Annual Bulletin of Statistics.

Lopez, R. E. (1984). Measuring Oligopoly Power and Production Response of the Canadian Food Processing Industry. Journal of Agricultural Economics. 35:219-230.

Quirmbach, H. C. (1988). Comparative Statics for Oligopoly: Demand Shift Effects. International Economic Review. 29:451-459.

Roberts, M. J. (1984). Testing Oligopolistic Behavior. International Journal of Industrial Organization. 2:367-383. 
Rude, J.I. (1992). The Impact of Trade Liberalization on the Canadian Dairy Processing Industry. Ph.D. Thesis, University of Guelph.

Schroeter, J. R. (1988). Estimating the Degree of Oligopoly Power in the Beef Packing Industry. Review of Economics and Statistics. 70:990-999.

TSP International (TSP Version 4.4).(1997). U.S.A.

Wann, J. J. and R. J. Sexton. (1992). Imperfect Competition in Multiproduct Food Industries with Application to Pear Processing. American Journal of Agricultural Economics. 74:980-990.

Weerahewa, J. (1996). Return from Investment under Imperfect Competition: Sri Lankan Tea Research, Promotion and Advertising. Thesis. Ph.D. University of Guelph. Ontario, Canada. 